\title{
Paradigma Pendidikan Islam Multikultural: Keberagamaan Indonesia dalam Keberagaman
}

\section{Payiz Zawahir Muntaha}

Universitas Islam Negeri Sunan Gunung Djati Bandung, Indonesia

Email: faizzawahir19@gmail.com

Ismail Suardi Wekke

Sekolah Tinggi Agama Islam Negeri Sorong, Papua Barat, Indonesia

Email: iswekke@gmail.com

\begin{abstract}
Abstrak
Pendidikan Islam di Indonesia telah menjadi pilar kebangsaan. Ketika Proklamasi belum diwujudkan, pendidikan Islam sudah menjadi bagian dari dinamika kebangsaan. Untuk itu, artikel ini mengkaji secara khusus bagaimana pendidikan Islam dalam upaya untuk mewujudkan pendidikan multikultural sebagai bagian dari praktik pembelajaran. Dengan proses pendidikan yang berbasis multikultural, akan memberikan kesempatan kepada tenaga kependidikan, murid, dan lingkungan masyarakat untuk senantiasa menerima perbedaan. Saat itu, kesempatan untuk saling menghargai, mengapresiasi, dan memberikan dukungan kepada pihak yang sekalipun berbeda, akan senantiasa menjadi nilai pendidikan. Akhirnya, gagasan pendidikan Islam multicultural sesungguhnya merupakan tuntutan dan keperluan masyarakat. Sehingga diperlukan langkah praktis untuk mewujudkan dalam proses pembelajaran yang dimulai dari pengembangan kurikulum sampai teknik pembelajaran. Ini tidak bisa dilakukan dengan mengubah tatanan kurikulum, hanya saja diperlukan sebuah usaha yang komprehensif yang mengintegrasikan prinsip-prinsip pendidikan multikultural dalam aktivitas pendidikan.
\end{abstract}

Kata Kunci: Islamic Education, Multicultural Education, Diversity

Indonesia sebagai bangsa yang memiliki aneka suku, agama, ras dan bahasa. Terdapat lebih dari 300 kelompok etnik atau suku bangsa di Indonesia (East, 1999, hal. 88) atau BPS menyatakan angka 1.340 suku bangsa (Gunawan \& Rante, 2011, hal. 212-224). Dengan kondisi yang begitu beragam, jalinan kebangsaan Indonesia sangat beragam. Kata Indonesia sendiri telah berhasil menyatukan 1340 suku yang tersebar diantara 17000 pulau yang memiliki agama, adat dan bahasa yang berbeda yang kemudian mempersatukan diri dibawah naungan satu nama. 
Payiz Zawahir Muntaha dan Ismail Suardi Wekke Paradigma Pendidikan Islam Multikultural: Keberagamaan Indonesia dalam Keberagaman

Kondisi ini menyebabkan Indonesia memiliki struktur budaya yang berbeda-beda dan unik di setiap wilayah. Perbedaan ini dapat dilihat dari perbedaan bahasa, adat istiadat, religi, tipe kesenian, dan lain- lain. Pada dasarnya suatu masyarakat dikatakan multikultural jika dalam masyarakat tersebut memiliki keanekaragaman dan perbedaan. Keragaman dan perbedaan yang dimaksud antara lain, keragaman struktur budaya yang berakar pada perbedaan standar nilai yang berbeda-beda, keragaman ras, suku, dan agama, keragaman ciri-ciri fisik seperti warna kulit, rambut, raut muka, postur tubuh, dan lain-lain, serta keragaman kelompok sosial dalam masyarakat.

Kebudayaan Indonesia merupakan identitas bangsa yang harus dihormati dan dijaga serta perlu dilestarikan agar kebudayaan kita tidak hilang dan bisa menjadi warisan generasi yang akan datang. Dikarenakan ketahanan budaya merupakan identitas suatu bangsa. Kebanggaan bangsa Indonesia akan budaya yang beraneka ragam sekaligus mengundang tantangan bagi seluruh rakyat untuk mempertahankan budaya lokal untuk bersinergi dengan dinamika dan perkembangan mutakhir (Bandel, 2011, hal. 7-8).

Masyarakat Indonesia telah hidup dengan damai ditengah keragaman budaya, bahasa dan agama. Kehidupan yang damai tercipta karena rasa persaudaran dan kekeluargaan yang tercipta yang disebabkan karena semua penduduk Indonesia telah mengalami penderitaan yang sama yang disebabkan oleh penjajahan. Sebagaimana spirit persaudaraan yang ada di Fak-Fak Papua Barat dikenal dengan semboyan "Satu Tungku Tiga Batu" sedangkan di Kepulauan Raja Ampat dikenal semboyan "Satu Rumah Empat Pintu". Kedua semboyan ini memiliki arti bahwa Islam, Protestan, Katolik, dan kepercayaan adat di Tanah Papua menjadi pilar dari kesatuan dan pembangunan Tanah Papua. Di samping Islam, Katolik, dan Protestan, animisme juga diberikan penghormatan yang sama sebagai bagian dari keluarga. Mereka memiliki keragaman agama antara satu dengan yang lainnya (Suardi, 2016, hal. 299-300).

Senada dengan kerukunan yang ada di Papua kita bisa menemukan dalam kehidupan di masyarakat Desa Kolam Kanan Kecamatan Barambai Kabupaten Barito Kuala memiliki toleransi. Dengan anggota masyarakat desa yang terdiri dari suku Bali, Banjar dan Jawa dan agama Islam, Hindu dan Kristen. Masyarakat desa kolam kanan hidup dengan rukun dan damai. Bagi masyarakat desa kolam kanan silaturahmi dan musyawarah menjadi prinsip yang dipegang teguh untuk menciptakan kehidupan yang damai ditengah perbedaan budaya dan agama yang ada dimasyrakatnya (Akhyar, 2015, hal. 726-731). 
Masyarakat sebagai suatu sistem yang secara keseluruhan terdiri dari bagian-bagian yang saling tergantung (interdependensi). Hal ini menyebabkan semua anggota masyarakat itu memiliki keterkaitan dan saling membutuhkan satu sama lain. Bagian-bagian dari masyarakat harus dipahami dalam relevansinya dengan fungsi terhadap keseimbangan sistem keseluruhan. Sehingga bagian-bagian tersebut menunjukkan gejala saling tergantung dan saling mendukung untuk memelihara keutuhan system (Muqoyyidin, 2012, hal. 325). Oleh sebab itu maka semua elemen yang ada di masyarakat haruslah bersatu untuk terciptanya kehidupan yang damai dan tercapainya tujuan bersama.

Kedamaian dan toleransi yang ada di Papua dan Desa Kolam Kanan membuktikan bahwa dalam lintasan sejarah bangsa Indonesia telah berhasil menciptakan kehidupan yang damai ditengah masyarakat yang multikultural. Akan tetapi, tanpa kita sadari bahwa kemajemukan tersebut juga menyimpan potensi konflik yang dapat mengancam kehidupan berbangsa dan bernegara. Hal ini telah terbukti di beberapa wilayah Indonesia terjadi konflik dimulai dari dekade 1990-an seperti di Sampit (antara Suku Madura dan Dayak), di Poso (antara Kristiani dan Muslim), di Aceh (antara GAM dan RI), ataupun perkelahian yang kerap terjadi antarkampung di beberapa wilayah di pulau Jawa dan perkelahian pelajar antarsekolah (Arifudin, 2007, hal. 1). Kekerasan antar kelompok yang meledak secara sporadis di akhir tahun 1990-an di berbagai kawasan di Indonesia menunjukkan rentannya rasa kebersamaan yang dibangun dalam negara-bangsa, betapa kentalnya prasangka antar kelompok, dan betapa rendahnya saling pengertian antar kelompok.

Berdasarkan laporan lembaga kajian dan penelitian berkenaan dengan toleransi serta kekerasan atas nama agama di Indonesia yang terjadi pasca reformasi. Laporan Moderate Muslim Society pada tahun 2010 yang mencatat adanya 81 kasus kekerasan agama. Laporan ini tentu saja sama sekali bukan gambaran sempurna karena tidak semua wilayah Indonesia masuk dalam jangkauan survey (Bagir, 2010; Penyusun, 2010). Selain dari itu di Jawa Timur terjadi 56 kasus yang bisa masuk dalam kategori pelanggaran kebebasan beragama dan berkeyakinan (Studies, 2010).

Hasil studi menunjukan ada dua isu utama dan kerap menjadi masalah, yaitu penodaan/ penyimpangan agama dan rumah ibadah (Bagir, 2011). Kedua hal ini menjadi isu utama karena dalam beberapa tahun ini, konflik-konflik di seputar isu itu kerap berubah menjadi kekerasan yang tak tertangani dengan baik. Lebih jauh lagi terdapat dua hal yang menjadi masalah utama, yaitu: (1) pelanggaran 
Payiz Zawahir Muntaha dan Ismail Suardi Wekke Paradigma Pendidikan Islam Multikultural:

Keberagamaan Indonesia dalam Keberagaman

kebebasan beragama, yang pelakunya adalah institusi negara (termasuk kantor kementerian, badan-badan negara, polisi, kantor pengadilan, tentara, dan juga pemerintah daerah, desa, kecamatan, kabupaten/ kota dan provinsi); dan (2) intoleransi atas dasar agama dan keyakinan, yang pelakunya dapat negara, tetapi juga kelompok-kelompok masyarakat (ormas, khususnya ormas keagamaan, individu, maupun massa yang tak teridentifikasi (Penyusun, 2011).

Untuk meminimalisir konflik yang sering terjadi ditengah masyarakat yang beragam, maka di sekolah harus ditanamkan nilai-nilai kebersamaan, toleran, dan agar peserta didik mampu menyesuaikan diri dalam berbagai perbedaan. Proses pendidikan ke arah ini dapat ditempuh dengan pendidikan multikultural. Proses pendidikan multikultural merupakan proses penanaman cara hidup menghormati, tulus, dan toleran terhadap keragaman budaya yang hidup di tengah-tengah masyarakat plural. Dengan pendidikan multikultural diharapkan adanya kelenturan mental bangsa menghadapi benturan konflik sosial.

Sikap atau prilaku ekslusif yang beranggapan bahwa diri dan golongannya yang paling benar adalah sikap yang dalam kehidupan social sangat rentan menimbulkan konflik. Selama pendidikan dipengaruhi oleh agama, maka pendidikan menimbulkan efek politik dan dan dimonopoli oleh kaum yang dominan. Karena efek politik yang begitu besar dalam pendidikan agama, tidak heran jika doktrin yang berkembang adalah doktrin yang eksklusif, superior dan truth claim. Pendidikan agama yang dikemas demikian, sampai batas tertentu akan mematikan hubungan harmonis dan menumpulkan sikap terbuka terhadap agamaagama lain. Agama hanya dijadikan sebagai ideologi politik yang sangat kental dengan aroma konflik dan pertikaian antar sesama umat beragama (Susanto, 2006, hal. 783).

Dalam realita kehidupan yang beragam pemahaman yang pendidikan Islam multikultural harus dihadirkan untuk memperluas wacana pemikiran keagamaan manusia yang selama ini masih mempertahankan "egoisme" keagamaan dan "etnosentrisme" kebudayaan. Oleh sebab itu multikultural dapat diartikan pula sebagai pluralitas kebudayaan dan agama. Dengan demikian, jika kebudayaan itu sudah plural, maka manusia dituntut untuk memelihara pluralitas agar terjadi kehidupan yang ramah dan penuh perdamaian. Pluralitas kebudayaan adalah interaksi sosial dan politik antara orang-orang yang berbeda cara hidup dan berpikirnya dalam suatu masyarakat. Secara ideal, pluralisme kebudayaan berarti penolakan terhadap kefanatikan, purbasangka, rasisme, tribalisme dan menerima secara inklusif keanekaragaman yang ada (Haviland, 1988, hal. 289-290). 
Sikap saling menerima, menghargai nilai, budaya, keyakinan yang berbeda tidak otomatis akan berkembang sendiri. Apalagi karena dalam diri seseorang ada kecenderungan untuk mengharapkan orang lain menjadi seperti dirinya. Sikap saling menerima dan menghargai akan cepat berkembang bila dilatihkan dan dididikkan pada generasi muda dalam sistem pendidikan nasional (Ibrahim, 2008, hal. 117). Dengan pendidikan, sikap penghargaan terhadap perbedaan yang direncana baik, generasi muda dilatih dan disadarkan akan pentingnya penghargaan pada orang lain dan budaya lain bahkan melatihnya dalam hidup sehingga sewaktu mereka dewasa sudah mempunyai sikap itu.

Jika cita ideal pendidikan seperti itu dapat terwujud di hati sanubari dan prilaku masyarakat, maka itulah yang disebut dengan pendidikan multikultural yang bermuara pada multikulturalisme. Multikulturalisme adalah aspek yang tidak terbantahkan bagi seluruh masyarakat Indonesia, entah hal itu disadari atau tidak. Dalam dunia multikultural harus mementingkan adanya berbagai macam perbedaan antara yang satu dengan yang lainnya dan ada interaksi sosial di antara mereka. Warga perlu menfokuskan pada pemahaman dan hidup bersama dalam konteks sosial budaya yang berbeda (Fay, 1998, hal. 3-4).

Metode penelitian yang digunakan dalam penelitian ini adalah Kualitatif (qualitative methode), dengan pendekatan Deskriptif Eksplanatoris. Pendekatan inilah yang dipandang relevan dengan masalah yang diteliti. Kemudian untuk menganalisis fakta-fakta yang ditemukan dilapangan, dilakukan langkah-langkah sebagai berikut: Pertama, reduksi data, yaitu melakukan penyusunan data yang diperoleh, kemudian ditentukan data yang sesuai dengan penelitian ini dengan pengklasifikasian. Sementara data yang kurang relevan dikesampingkan. Kedua, dari kompleksitas data yang penting dan relevan di atas, kemudian dilakukan pengklasifikasian data dalam beberapa titik tekan persoalan yang sesuai dengan penelitian. Ketiga, dilakukan pengolahan data secara kualitatif. Dalam tahapan ini setiap data diberikan pengertian sehingga mudah untuk dipahami. Pengertian ini dimaksudkan untuk menganalisis inti pemikiran yang ada di dalam data.

\section{Menggagas Pendidikan Islam Multikultural}

Problem-problem sosial ekonomi yang terjadi di masyarakat, seperti masalah disintegrasi, kemiskinan, kemunduran akhlak sudah semakin terbuka dan merajalela di masyarakat. Lembaga pendidikan Islam diharapkan tidak saja mampu menyelesaikan masalah-masalah yang terkait dengan faham keagamaan, tetapi juga diharapkan dapat terlibat menyelesaikan masalah-masalah sosial. 
Payiz Zawahir Muntaha dan Ismail Suardi Wekke Paradigma Pendidikan Islam Multikultural:

Keberagamaan Indonesia dalam Keberagaman

Peran strategis dimiliki oleh pendidikan Islam dalam usaha menciptakan kehiduapan yang damai di nusantara. Pesantren sebagai cikal bakal lembaga pendidikan Islam di Indonesia memang tumbuh dan berkembang pesat pada abad semenjak abad kesembilanbelas. Pada abad kesembilan belas di Jawa terdapat tidak kurang 1.853 pesantren, dengan jumlah santri tidak kurang dari 16.500 santri. Jumlah tersebut belum termasuk pesantren-pesantren yang berkembang di luar Jawa seperti di Sumatra, Kalimantan (Akhiruddin, 2015, hal. 199).

Lembaga pendidikan Islam berkembang sesuai dengan tuntutan lingkungan dan masyarakat. Kementrian Agama Republik Indonesia mendata jumlah lembaga pendidikan Islam sebanyak 300.270 yang meliputi Raudlatul Athfal hingga perguruan tinggi. Meliputi 675 perguruan tinggi, termasuk sebanyak 55 perguruan tinggi berstatus negeri. Di tambah Madrasah dari berbagai tingkatan, yaitu mulai dari diniyah hingga aliyah, dengan total berjumlah 75.199 lembaga.Sekaligus diantaranya sebanyak 27.290 Pondok Pesantren yang tersebar di seluruh tanah air (Indonesia, 2010, hal. 15). Termasuk madrasah-madrasah yang berusaha untuk tetap wujud karena berada di daerah minoritas muslim (Wekke, 2016, hal. 26).

Dengan kuantitas lembaga pendidikan Islam di Indonesia tersebut, diharapkan akan mampu menciptakan serta memperkokoh karakter bangsa Indonesia sebagai bangsa yang beradab dan bertoleransi tinggi. Oleh sebab itu, gagasan pendidikan Islam berwawasan multikultural diaplikasikan di Indonesia khususnya di lembaga pendidikan Islam. Dengan peran yang begiu penting maka lembaga pendidikan Islam menjadi fondasi kebangsaan dan kebernegaraan Indonesia.

Dengan demikian ada dua pokok peran strategis lembaga pendidikan Islam, yaitu mencetak kader ulama' yang mendalami ilmu agama dan pada saat yang sama mengetahui, terampil, dan peduli terhadap persoalan keummatan dan kebangsaan. Lemabaga pendidikan Islam adalah tempat untuk mencetak kader pemimpin bangsa yang "faqih fi 'ulum al-din dan faqih fi mashalih al-ummah". Lulusan lembaga pendidikan Islam diharapkan baik agamanya dan pandai untuk menghadapi persoalan umat dan bangsa.

Dengan peran semacam ini, dimungkinkan lembaga pendidikan Islam terlibat maksimal dalam membangun bangsa ini. Melalui lembaga pendidikan para santri atau siswa belajar ilmu-ilmu agama dan ilmu sosial yang dibutuhkan masyarakat. Bahkan seterusnya lembaga pendidikan Islam menjadi lembaga 
pengkaderan bagi santri atau siswa yang kelak siap terjun di masyarakat (Haningsih, 2008, hal. 34-37).

Kata multikultural, diartikan sebagai keragaman budaya peserta didik sebagai bentuk keragaman latar belakang seseorang. Dengan demikian, secara etimologis pendidikan multikultural didefinisikan sebagai pendidikan yang memperhatikan keragaman budaya peserta didik. Keragaman latar belakang yang dimiliki oleh peserta didik dijadikan sebagai fondasi dalam menyusun materi dan proses pembelajaran. Secara terminologis, definisi pendidikan multikultural sangat beragam. Pendidikan multikultural adalah konsep, ide atau falsafah sebagai suatu rangkaian kepercayaan (set of believe) dan penjelasan yang mengakui dan menilai pentingnya keseragaman budaya dan etnis di dalam membentuk Gaya hidup, pengalaman sosial, identitas pribadi, kesempatan-kesempatan pendidikan dari individu, kelompok, maupun Negara (Tilaar, 2004, hal. 181).

Pada awalnya gagasan pendidikan multikultural muncul pada lembaga lembaga pendidikan tertentu di wilayah Amerika yang pada awalnya diwarnai oleh sistem pendidikan yang mengandung diskriminasi etnis, yang kemudian belakangan hari mendapat perhatian serius dari pemerintah. Pendidikan multikultural sendiri merupakan strategi pembelajaran yang menjadikan latar belakang budaya siswa yang bermacam-macam digunakan sebagai usaha untuk meningkatkan pembelajaran siswa di kelas dan lingkungan sekolah. Hal demikian ini dirancang untuk menunjang dan memperluas konsep-konsep budaya, perbedaan, kesamaan dan demokrasi (Ali, 2010, hal. 168).

Pendidikan Islam multikultural juga dapat dipahami sebagai proses pendidikan yang berprinsip pada demokrasi, kesetaraan dan keadilan; berorientasi kepada kemanusiaan, kebersamaan, dan kedamaian; serta mengembangkan sikap mengakui, menerima dan menghargai keragaman berdasarkan al-Qur'an dan hadis (Aly, 2011, hal. 19). Secara normative al-Qur'an menegaskan bahwa manusia memang diciptakan dengan latar belakang yang beragam.

Multikulturalisme sebagai sebuah paham yang menekankan pada kesenjangan dan kesetaraan budaya-budaya lokal dengan tanpa mengabaikan hakhak dan eksistensi budaya yang ada. Oleh sebab itu penekanan utama multikulturalisme adalah pada kesetaraan budaya (Naim \& Sauqi, 2008, hal. 125). Paradigma pembangunan pendidikan Indonesia yang sentralistik telah melupakan keragaman yang sekaligus kekayaan dan potensi yang dimiliki oleh bangsa ini. Perkelahian, kerusuhan, permusuhan, munculnya kelompok yang memiliki 
Payiz Zawahir Muntaha dan Ismail Suardi Wekke Paradigma Pendidikan Islam Multikultural:

Keberagamaan Indonesia dalam Keberagaman

perasaan bahwa hanya budayanyalah yang lebih baik dari budaya lain adalah buah dari pengabaian keragaman tersebut dalam dunia pendidikan.

Ada dua masalah penting yang saling terkait dalam peningkatan kualitas hidup manusia adalah masalah pendidikan dan kebudayaan. Di satu pihak, pengembangan dan pelestarian kebudayaan dalam proses pendidikan dan membutuhkan perekayasaan pendidikan. Sementara itu, pengembangan pendidikan juga membutuhkan suatu sistem kebudayaan sebagai akar dan pendukung berlangsungnya proses pendidikan. Namun dalam proses pengembangannya kebudayaan membutuhkan kebebasan-kreatif sedangkan pendidikan membutuhkan stabilitas.

Adapun ciri-ciri masyarakat yang ingin dikembangkan dengan multikulturalisme, maka sesuatu yang akan menjadi spesifik atau khusus adalah berkenaan dengan penataan ruang publik dan ruang privat tersebut adalah mengacu pada identitas kesepakatan dan dinamika yang berkembang di negara masingmasing, yang tidak dapat diganggu gugat oleh negara lain, kecuali menyangkut "ruang publik antar-negara", yang perlu ditata secara bersama pula, misalnya dalam PBB dan bentukbentuk ikatan antar-negara lainnya (Harahap, 2006 , hal. 33).

Bagi bangsa seperti Indonesia yang memiliki keragaman suku, budaya, bahasa dan agama pendidikan yang berwawasan multikultural adalah sebuah keharusan. Yaitu suatu bentuk pendidikan yang berusaha menjaga dan mewariskan kebudayaan dan keragaman suatu masyarakat kepada generasi selanjutnya. Pendidikan yang memupuk rasa persaudaraan dan persahabatan diantara siswa yang memliki keragaman latar belakang ras, bahasa, dan agama. Juga mengajarkan sikap saling memahami satu sama lain demi tercapainya kehidupan yang damai dan masyarakat yang toleran ditengah perbedaan.

Pendidikan Islam bukan hanya sekadar transfer of knowledge, tetapi lebih merupakan suatu sistem yang ditata di atas pondasi keimanan dan kesalehan, suatu sistem yang terkait langsung dengan teologi. Dengan demikian, pendidikan Islam adalah suatu kegiatan yang mengarahkan dengan sengaja perkembangan seseorang sesuai atau sejalan dengan nilai-nilai Islam. Pendidikan Islam dapat digambarkan sebagai suatu sistem yang membawa manusia ke arah kebahagiaan dunia dan akhirat melalui ilmu dan ibadah.

Dalam kaitan dengan kebangsaan, pengembangan pendidikan nasional haruslah menterjemahkan nilai-nilai yang terkandung pada budaya bangsanya. Budaya bangsa tersebut meniscayakan pemahaman terhadap tradisi-tradisi daerah yang tidak boleh diilangkan dalam proses pembelajaran. Oleh sebab itu, proses 
pembelajaran haruslah melestarikan dan menghargai akar kebudayaan dan keragaman yang dimiliki oleh setiap wilayah dan smeua peserta didik sebagai identitas nasional. Multikulturalisme baik pada tingkat lokal, nasional, dan global pada umumnya mengedepankan prinsip keadilan dan persamaan. Untuk mewujudkan prinsip multikulturalisme tersebut, yang dibutuhkan sekarang bukan monokulturalisme, bukan pembauran tetapi pembaruan, bukan koeksistensi tetapi pro eksistensi, bukan ekslusi tetapi inklusi, dan bukan separasi tetapi interaksi. Dengan pola pendidikan yang berwawasan multikulturalisme maka kedamaian dan toleransi yang dari dahulu sudah dimiliki oleh bangsa Indonesia akan terjaga dan terwariskan pada generasi yang akna datang.

Sebagai konsekuensi logis dalam kehidupan di era plural, kenyataan multikulturalisme tidak dapat dihindarkan, karena itu pendidikan yang terkait dengan multikultural adalah keharusan. Pendidikan yang dimaksud dapat diuraikan dalam tiga sub-nilai sebagaimana konsep Lawrence, yaitu pertama, penegasan identitas kultural seseorang. Identitas kultural seseorang merupakan entitas fundamental dalam kehidupannya, dan itulah yang membedakannya dengan orangorang di luar dirinya. Walaupun sebagai entitas fundamental dalam kehidupan seseorang, identitas tidak seharusnya ekslusif dan tidak berinteraksi dengan identitas-identitas eksternal, melainkan menampakkan wajah yang mengedepankan nilai-nilai kemanusiaan yang adil dan beradab yang merupakan tujuan dari pendidikan multikultural.

Kedua, penghormatan dan keinginan untuk memahami dan belajar dari kebudayaan-kebudayaan selain kebudayaannya. Memahami kebudayaan sesama manusia merupakan aspek penting dalam kehidupan di era plural. Kebudayaan orang lain di luar diri dan kelompoknya harus dijadikan kawan dialogis untuk mengetahui kelebihan dan kebenaran yang hadir bersama budaya eksternal tersebut. Kelebihan dan kebenaran yang dibawa oleh budaya luar inilah yang membantu pengembangan budaya internal seseorang. Ketiga, perasaan senang dengan perbedaan kebudayaan itu sendiri. Perbedaan adalah rahmat yang diberikan Tuhan kepada umat manusia dengan tujuan berkompetisi meraih kebaikan. Untuk itu, perbedaan harus dihargai dan disenangi bukan dibenci dan dicaricari kesalahannya, sehingga melahirkan konflik horizontal sosial agama.

Dalam konteks kehidupan yang plural terdapat lima model multikulturalisme yang dapat menjadi acuan penyelenggaraan pendidikan di tanah air. Penyelenggara pendidikan dapat memilah dan memilih mana di antaranya yang tepat dan relevan untuk konteks Indonesia. Kelima model multikulturalisme yang 
Payiz Zawahir Muntaha dan Ismail Suardi Wekke Paradigma Pendidikan Islam Multikultural: Keberagamaan Indonesia dalam Keberagaman

dimaksud adalah: Pertama, "multikulturalisme isolasionis" yang mengacu kepada masyarakat dimana berbagai kelompok kultural menjalankan hidup secara otonom dan terlibat dalam interaksi yang hanya minimal satu sama lain. Contoh-contoh kelompok ini adalah seperti masyarakat yang ada pada sistem "milled" di Turki Usmani atau masyarakat Amish di A.S. Kelompok ini menerima keragaman, tetapi pada saat yang sama berusaha mempertahankan budaya mereka secara terpisah dari masyarakat lain pada umumnya.

Kedua, "multikulturalis me akomodatif", yakni masyarakat plural yang memiliki kultur dominan yang membuat penyesuaian dan akomodasi-akomodasi tertentu bagi kebutuhan cultural kaum minoritas. Masyarakat multikultural akomodatif merumuskan dan menerapkan undang-undang, hukum, dan ketentuanketentuan yang sensitif secara kultural, dan memberikan kebebasan kepada kaum minoritas untuk mempertahankan dan mengembangkan kebudayaan mereka. Sebaliknya kaum minoritas tidak menentang kultur yang dominan. Kelompok ini dapat ditemukan di Inggris, Prancis, dan beberapa Negara Eropa lainnya.

Ketiga, "multikulturalisme otonomis" yakni masyarakat plural dimana kelompok-kelompok kultural utama berusaha mewujudkan kesetaraan (equality) dengan budaya dominant dan menginginkan kehidupan otonom dalam kerangka politik yang secara kolektif bisa diterima. Konsern pokok kelompok-kelompok kultural terakhir ini adalah untuk mempertahankan cara hidup mereka yang memiliki hak yang sama dengan kelompok dominan; mereka menantang kelompok kultural dominan dan berusaha menciptakan suatu masyarakat dimana semua kelompok bisa eksis sebagai mitra sejajar. Jenis kelompok ini didukung oleh kelompok Iuebecois di Kanada, dan kelompok-kelompok muslim imigran di Eropa, yang menuntut untu bisa menerapkan syari'ah, mendidik anak-anak mereka pada sekolah Islam dan sebagainya.

Keempat, "multikulturalisme kritikal" atau "interaktif", yakni masyarakat plural dimana kelompok-kelompok kultural tidak terlalu konsern dengan kehidupan kultural otonom, tetapi lebih menuntut penciptaan kultur kolektif yang mencerminkan dan menegaskan perspektif-perspektif distingtif mereka. Kelompok budaya dominan tentu saja cenderung menolak tuntutan ini, dan bahkan berusaha secara paksa untuk menerapkan budaya dominan mereka dengan mengorbankan budaya-budaya kelompok-kelompok minoritas. Karena itulah kelompok-kelompok minoritas menantang kelompok kultur dominan, baik secara intelektual maupun politis, dengan tujuan menciptakan iklim yang kondusif bagi penciptaan sebuah 
kultur kolektif baru yang egaliter secara genuine. Jenis kelomopk diperjuangkan oleh masyarakat kulit hitam di A.S, Inggris, dan lain-lain.

Kelima, "multikulturalisme kosmopolitan", yang berusaha menghapuskan batas-batas kultural sama sekali untuk menciptakan sebuah masyarakat di mana setiap individu tidak lagi terikat dan committed kepada budaya tertentu dan begitu juga sebaliknya, secara bebas terlibat di dalam eksperimen-eksperimen interkultural dan sekaligus mengembangkan kehidupan kultural masing-masing. Pendukung jenis ini biasanya intelektual diasporik dan intelektual liberal yang cenderung pada postmodernis.

Lima klasifikasi multikulturalisme di atas tidak semuanya cocok untuk konteks Indonesia. Yang perlu dilakukan oleh penyelenggara pendidikan adalah menyaring kira-kira multikulturalisme mana yang tepat atau paling tidak mendekati tujuan meminimalisir konflik horizontal. Karena ragam dan macam multikulturalisme itulah yang melahirkan pendidikan multikultural, yaitu pendidikan untuk/tentang keragaman kebudayaan dalam merespon perubahan demografis dan kultural lingkungan masyarakat tertentu atau bahkan dunia secara keseluruhan.

Pendidikan multikultural merupakan suatu konsep yang menyatakan bahwa seluruh peserta didik tanpa memperhatikan dari kelompok mana mereka berasal, seperti gender, etnik, ras, budaya, kelas sosial, agama, dan lain-lain diharapkan dapat memperoleh pengalaman pendidikan yang sama di sekolah atau lembaga pendidikan (Banks \& Banks, 1997, hal. 26). Pendidikan multikultural juga dapat diartikan sebagai sebuah gerakan reformasi yang dirancang untuk menghasilkan sebuah transformasi di sekolah, sehingga peserta didik baik dari kelompok gender maupun dari kelompok budaya dan etnik yang berbeda akan mendapat kesempatan yang sama untuk menyelesaikan sekolah.

Pendidikan multikultural menganggap sekolah sebagai sebuah sistem sosial (school as a social system) yang terdiri dari bagian-bagian dan variabel-variabel yang saling terkait. Maka, untuk membentuk sekolah yang menjunjung tinggi persamaan kesempatan memperoleh pendidikan, seluruh komponen utama dari sekolah secara substantif harus diganti. Jika hanya salah satu variabel dari sekolah, seperti kurikulumnya saja yang diganti, maka hal itu tidak dapat menghasilkan pendidikan multikultural). Suyata juga mengatakan bahwa untuk mencapai pendidikan multikultural dalam sistem persekolahan, sekolah tidak dapat dibangun berdasarkan budaya elit. Sekolah perlu mengubah strategi budaya dari elit ke mayoritas budaya rakyat yang sangat plural. Dengan strategi ini, mobilisasi, 
Payiz Zawahir Muntaha dan Ismail Suardi Wekke Paradigma Pendidikan Islam Multikultural: Keberagamaan Indonesia dalam Keberagaman

dukungan, dan keikutsertaan masyarakat secara luas dapat diwujudkan (Suyata, 2001, hal. 21). Kurikulum sejatinya merupakan cerminan keperluan dan tuntutan masyarakat (Wekke, 2016, hal. 372-392).

Tujuan utama pendidikan multikultural untuk mengubah seluruh lingkungan atau suasana pendidikan, sehingga dengan pendidikan multikultural dapat meningkatkan rasa saling menghormati dan peduli terhadap kelompok-kelompok budaya yang lain untuk mendapatkan pendidikan yang sama (Banks J. A., 1987, hal. 29-30). Oleh sebab itu maka tujuan utama paradigm pendidikan multikultural merupakan tujuan utama dari proses pembelajaran seumur hidup (life long learning) (Pay, 1990, hal. 109). Bahkan dalam pembelajaran di dalam kelas sekalipun, prinsip multikutural perlu diaplikasikan dalam bentuk teknik dan gaya pembelajaran (Wekke \& Lubis, 2016).

Masalah utama yang terkait dengan pendidikan multikultural adalah keadilan sosial, demokrasi, dan hak asasi manusia Ketiga aspek tersebut, walaupun terkait erat dengan aspek ekonomi, politik dan hukum, bukan berarti tidak ada hubungannya dengan pendidikan. Hemat penulis, justru pendidikan memiliki peran signifikan untuk mencetak manusia-manusia yang berkeadilan sosial, memiliki visi politik yang demokratis, dan menunjung tinggi hak dan martabat orang lain. Tidak mengherankan apabila pendidikan multikultural berkaitan dengan isu-isu politik, sosial, kultural, moral, edukasional dan agama. Tanpa kajian bidang-bidang ini maka sulit untuk diperoleh suatu pengertian mengenai pendidikan multicultural (Tilaar, 2004, hal. 167-168).

\section{Multikulturalisme Sebagai Paradigma Pendidikan Islam}

Penganut relativisme dengan berpendapat bahwa semua agama adalah sama benarnya "every religion is a true and equally valid as every other" dimana kebenaran bukan monopoli agama tertentu. Tidak dibenarkan pemeluk sutatu agama menyalahkan atau menganggap sesat agama yang lain. Pandangan ini merupakan induk dari paham esensialisme, singkretisme dan pluralisme agama. Maka kekeliruan ketiga faham ini pun tidak jauh berbeda dan tidak dapat dipisahkan dengan relativisme (Arif, 2008).

Paradigma pluralisme berangkat dari keinginan mencari titik temu antara agama-agama yang berbeda. Dalam hal ini pluralisme tidak menyamakan semua agama tentunya jika pluralisme menyamakan semua agama maka pluraliitas itu sendiri sudah tidak ada. Pluralisme agama meupakan persenyawaan tiga preposisi. Pertama, semua tradisi agama besara adalah sama, semua merujuk dan menunjuk 
realitas tunggal yang transenden dan suci. Kedua, semua sama-sama menawarkan jalan keselamatan. Dan yang ketiga, semua tidak ada yang final, artinya semua agama harus selalu terbuka untuk dikritisi dan direvisi (Byrne, 1995).

Setidaknya ada tiga model kebijakan multikultural yang bisa diimplementasikan sebuah negara untuk menyikapi keadaan bangsa yang beragama diataranya: pertama, model yang mengedepankan nasionalitas, nasuionalitas adalah hal baru yang dibangun bersama tanpa memperhatikan aneka ragam suku bangsa, agama dan bahasa. Nasionalitas berfungsi sebagai perekat integrasi bangsa dan negara. Dalam model ini setiap orang berhak untuk dilindungi oleh negara. Model kebijakan ini dipandang sebagai model yang bisa menghancurkan akar kebudayaan dan kebijaksanaan etnik yang menjadi dasar pembentukan negara dan menjadikannya hanya masalalu saja.

Kedua, model nasionalitas-etnik yang berdasarkan kesdadaran kolektif etnik yang kuat yang landasannya adalaha hubungan darah dan kekerabatan dengan para pendiri nasional. Selain dari itu kesatuan bahasa juga merupakan ciri nasionalitas-etnik ini. Model ini dianggap sebagai model tertutup karena orang luar yang tidak memiliki hubungan dengan pendiri nasionalitas-etnik ini akan tersingkir dan diperlakukan sebagai orang asing. Ketiga, model multikultural-etnik yang mengakui dan melindungi hak-hak warga etnik. Dalam model ini keanekaragaman menjadi realitas yang harus dilindungi dan diakui oleh negara. Isu yang akan muncul dalam penerapan model ini adalah isus minoritas dan mayoritas atau siapa yang dominan dan tidak dominan. Permasalahan bisa menjadi lebih kompleks karena tidak selalu mayoritas menjadi kelompok yang dominan (Maksum, 2011, hal. xviii).

Akan tetapi pendidikan Islam yang plural tidak bertujuan untuk menanamkan nilai-nilai sinkretisme, relativisme dan esensialisme. Karena jika hal ini menjadi tujuan dari pendidikan Islam yang berwawasan plural dan multikultural maka akan menghasilkan Patchwork Religion atau agama gado-gado hasil kombinasi ajaran-ajaran yang sama dari semua agama dan membuang ajaran yang masih diperdebatkan. Contohnya sikhisme di India, Baha'isme di Iran, Cuadaisme di Vietnam atau aliran kebathinan semacam Sumarah, Pangestu, Darmo, Gandul dan lain sebagainya di indonesia.

Maka dalam hal ini pendidikan Islam yang berwawasan plural dan multikultural bertujuan untuk memberikan pemahaman kepada peserta didik akan realitas yang majemuk, serta memberikan pendidikan tentang cara bersikap menyikapi realitas yang berbeda. Di Indonesia, pluralisme kerap dipadankan dengan inklusivisme yang diartikan sebagai paham keagamaan yang mengakui dan 
Payiz Zawahir Muntaha dan Ismail Suardi Wekke Paradigma Pendidikan Islam Multikultural: Keberagamaan Indonesia dalam Keberagaman

menerima bahwa agama lain memiliki potensi kebenaran dan berhak untuk menjalankan aktivitas keagamaannya demi terwujudnya kebersamaan dan kerukunan antar umat beragama tanpa mereduksi kecintaan akan kebenaran mutlak pada agama yang dipeluk

Pendidikan Islam selama ini dianggap sebagai pabrik intelektual yang mampu melahirkan akto-aktor pembangunan yang cerdas dan berkepribadian, juga mempunya kemampuan untuk dapat melestarikan budaya "transmission od culture" dan mampu memprediksi masa depan atau mempunyai wawasan keakanan "infunture". Adapun dalam proses pelaksanaannya pendidikan multikultural tidaklah harus mengubah kurikulum. Materi pendidikan multikultural dapat terintegrasi pada mata pelajaran lainnya. Tidak perlu menjadi satu mata pelajaran tersendiri (Wekke, 2015, hal. 20-38). Hanya saja diperlukan keterampilan bagi guru untuk menerapkannya. Hal utama kepada para siswa perlu diajari mengenai toleransi, kebersamaan, HAM, demokratisasi, dan saling menghargai. Kesempatan tersebut, akan menjadi peluang bagi bekal hidup mereka di kemudian hari dan sangat penting untuk tegaknya nilai-nilai kemanusiaan.

Dalam proses pelaksanaannya sekolah memegang peranan penting untuk menanamkan nilai multikultural pada siswa sejak dini. Bila sejak awal mereka telah memiliki nilai-nilai kebersamaan, toleran, cinta damai, dan menghargai perbedaan, maka nilai-nilai tersebut akan tercermin pada tingkah-laku mereka seharihari karena terbentuk pada kepribadiannya. Bila hal tersebut berhasil dimiliki para generasi muda kita, maka kehidupan mendatang dapat diprediksi akan relatif damai dan penuh penghargaan antara sesama dapat terwujud.

Paradigma ini dimaksudkan bahwa, hendaknya ada apresiatif terhadap budaya orang lain, perbedaan dan keberagaman merupakan kekayaan dan khazanah bangsa Indonesia. Berdasarkan pandangan tersebut, diharapkan sikap ekslusif yang selama ini bersemayam dalam otak dan sikap membenarkan pandangan sendiri (truth claim) dengan menyalahkan pandangan dan pilihan orang lain dapat dihilangkan atau paling tidak diminimalisir.

Dalam konteks ini, paradigma pendidikan multikultural memberi pelajaran kepada kita untuk memiliki apresiasi respek terhadap budaya dan agama-agama orang lain. Atas dasar ini maka penerapan multikulturalisme menuntut kesadaran dari masing-masing budaya lokal untuk saling mengakui dan menghormati keanekaragaman budaya yang dibalut semangat demokratisasi, kerukunan, dan perdamain. Paradigma multicultural mengharuskan pendidikan diselenggarakan secara demokratis dan berkeadilan tanpa diskriminasi dengan menjunjung tinggi 
hak asasi manusia (HAM), nilai keagamaan, nilai kultural, dan kemajemukan bangsa (Indonesia R., 2013, hal. 7).

Proses pendidikan sebagai media pengembangan pola keberagamaan berbasis inklusivisme, pluralis dan multikultural, sehingga pada akhirnya dalam kehidupan masyarakat tumbuh pemahaman keagamaan yang toleran, inklusif dan berwawasan multikultur, sebab dengan tertanamnya kesadaran demikian, sampai batas tertentu akan menghasilkan corak paradigma beragama yang hanief. Ini semua mesti dikerjakan pada level bagaimana membawa pendidikan agama dalam paradigma yang toleran dan inklusif.

Filosofi pendidikan yang hanya membenarkan salah satu agama tertentu saja, tanpa mau menerima kebenaran agama lain, perlu dikritisi untuk selanjutnya dibenahi dan dilakukan reorientasi. Konsep iman-kafir, muslim non-muslim, dan truth claim yang sangat berpengaruh terhadap cara pandang masyarakat pada agama lain, semestinya "dibongkar" agar derivasinya yaitu sikap sosial yang bersif at eksklusif dan apologetik.

Karena itu, dengan meminjam filsafat pendidikan yang dikembangkan Paolo Freire yang menegaskan bahwa pendidikan harus difungsikan untuk pembebasan (liberation) dan bukan penguasaan (domination). Pendidikan harus menjadi proses pemerdekaan, bukan domestikasi dan bukan penjinakan sosial budaya (social and cultural domestication). Pendidikan bertujuan menggarap realitas manusia sehingga secara metodologis bertumpu pada prinsip aksi dan refleksi total, yakni prinsip bertindak untuk mengubah realitas yang menindas sekaligus secara bersamaan dan terus-menerus berusaha menumbuhkan kesadaran akan realitas dan hasrat untuk mengubah kenyataan yang menindas tersebut (Freire, 1986).

Dengan perspektif ini, maka kini kita mesti melakukan pembebasan terhadap pendidikan agama yang selama ini dilakukan, dengan memberi warna yang lebih menekankan dimensi inklusivitas. Dalam kondisi demikian, yang perlu dilakukan adalah melakukan reorientasi visi pendidikan agama yang berbasis eksklusif-monolitis ke arah penguatan visi inklusif multikulturalis. Hal ini dilakukan karena telah terjadi kegagalan dalam mengembangkan semangat toleransi dan pluralitas dalam pendidikan agama, yang pada gilirannya telah menumbuhsuburkan gerakan radikalisme agama. Hal inilah yang mesti kita renungkan bersama agar pendidikan agama kita tidak menyumbangkan benih-benih konflik antar agama. 
Payiz Zawahir Muntaha dan Ismail Suardi Wekke Paradigma Pendidikan Islam Multikultural: Keberagamaan Indonesia dalam Keberagaman

Karena itu, kebijakan pendidikan yang mengeliminasi arti signifikan keanekaragaman dan kemajemukan agama, perlu diantisipasi bersama, sehingga dalam merancang sistem pendidikan tidak hanya mengandalkan basis kognisi, tetapi juga bagaimana membentuk kesadaran beragama dalam tata pergaulan masyarakat yang damai dan sejahtera. Merancang sistem pendidikan agama justru menampung nilai-nilai luhur yang mendasari kehidupan masyarakat secara lebih substansial. Dengan logika pendidikan agama seperti itulah, kita dapat berharap tercipta tata kehidupan yang menghargai pluralitas, toleran dan mengupayakan kehidupan damai di tengah-tengah masyarakat.

\section{Visi Multikullturalisme Pendidikan Islam Indonesia}

Secara ideal fungsi pendidikan Islam sesungguhnya memliki fungsi kultural untuk melestarikan dan mewariskan cita-cita masyarakat yang didukungnya. Dalam fungsi ideal ini sebuah lembaga pendidikan Islam bertugas untuk mengarahkan dan mengontrol perkembangan masyarakat (Drajat \& Muchtarom, hal. 123-124). Lembaga pendidikan sebagai mesin ilmu penegetahuan yang akan mengarahkan pembangunan dan corak peradaban yang akan dibangun. Oleh sebab itu, pendidikan haruslah berorientasi untuk mengembangkan dan menjaga nilai-nilai budaya lokal dengan senantiasa berinovasi untuk menjadi lebih baik.

Islam sebagai agama universal yang oleh pemeluknya diakui sebagai pandangan hidup dalam aktivitas sehari-hari mensejajarkan "juktaposisi" pendidikan pada posisi yang sangat strategis. Pendidikan diasumsikan sebagai penentu segalan-galanya bagi kepentingan "vested interest" manusia di dunia, maka pendidikan Islam tidak dipandang secara fungsional sebagai sarana pemuas kebutuhan manusia yang sesaat di dunia. Lebih dari itu pendidikan menjangkau kebutuhan akhir dan esensial manusia di akhirat kelak.

Term pendidikan Islam mencakup semua muatan nilai didalamnya. Pengertian pertama bahwa pendidikan Islam adalah suatu proses pendidikan yang diselenggarakan oleh lembaga-lembaga Islam (An-nahlawi, 1992, hal. 32). Pengertian kedua adalah semua lembaga yang memberikan kontribusi pada proses pembumian ajaran Islam. Baik lembaga pendidikan yang secara eksplisit berdiri diatas label pendidikan Islam maupun institusi pendidikan umum tetapi secara implisit bedimensi atau berciri khas keagamaan (Steenbrink, 1986).

Kata-kata pendidikan yang berciri khas keagamaan digunakan untuk menyebutkan dua hal, yaitu: (1) Keseluruhan lembaga yang mendasarkan segenap kegiatan pendidikan atas pandangan serta nilai-nilai agama kepada peserta didiknya, 
dan (2) Segenap kegiatan yang dilakukan oleh seseorang atau suatu lembaga untuk mengajarkan pengetahuan agama kepada peserta didiknya melingkupi dimensi struktural ataupun fungsionalnya (Ali \& Arsyraf, 1986, hal. 1). Pengertian ketiga, pendidikan Islam menanamkan ajaran Islam kepada peserta didik, dimana tidak akan terlaksana tanpa bersandar kepada landasan organik Islam, yaitu Qur'an, Assunnah dan Sirah Nabawiyah (Marimba, 1986, hal. 23-24).

Keuniversalan dan kekekalan Islam terletak pada doktrin dan ajarannya yang sesuai dan sejalan dengan fitrah manusia, sehingga tidak terjadi kebimbangan dan keraguan bagi orang yang telah percaya dan meyakini agama tesebut, lain halnya dengan agama-agama yang lainnya, misalnya agama Kristen, dimana doktrin dan ajaran serta keyakinan yang terdapat di dalamnya, antara satu dengan yang lainnya terdapat pertentangan sehingga tidak membuat pemeluknya tenang dan mantap, malah sebaliknya membuat mereka bimbang dan ragu dengan apa yang mereka yakini. Pun dengan ajaran agama yang lain baik agama samawi ataupun agama ardy selain dari Islam pada saat ini memiliki ilat atau kejanggalan ajaran yang tidak sesuai dengan fitrah manusia (Madjid, 1994).

Ada dua fakta yang perlu dikemukakan sehubungan dengan merebaknya konflik dalam masyarakat yang berlarut-larut. Pertama, dalam sejarahnya pertemuan agamaagama dan perbenturan kadang-kadang tidak terelakkan, karena masalah agama lebih sensitif dibanding dengan yang lainnya. Dalam hubungan antara Islam dengan agama lain, ajaran Islam dengan tegas mengatakan bahwa "bagimu agamamu dan bagiku agamaku" (al-Kafirun: 6) dan pengakuan Nashrani dalam keputusan Vatikan II "gereja memandang umat Islam dengan penuh hormat". Kedua, bila diamati dalam kurun waktu tiga dekade di penghujung abad XX dan awal abad XXI, ada dua gejala sosial yang muncul ke permukaan, yaitu fenomena sosiokultural yang menggej ala pada masyarakat postmodern (postmodernity), dan fenomena transmisi global seperangkat "kesadaran dan institusi" modern (sosial, ekonomi, dan budaya) hingga menyentuh masyarakat yang belum modern yang disebut juga "globalisasi" (Baidhawi \& Toyibi, 2005, hal. 232-233).

Pendidikan multikultural merupakan proses penanaman nilai-nilai dan cara hidup menghormati, tulus, dan toleran terhadap keragaman budaya yang hidup di tengah-tengah masyarakat plural. Dengan pendidikan multikultural diharapkan adanya kelenturan mental bangsa menghadapi benturan konflik sosial. Dengan pola fikir yang ramah akan perbedaan maka dengan sendirinya akan tercipta prilaku dan struktur masyarakat yang toleran dan damai. 
Payiz Zawahir Muntaha dan Ismail Suardi Wekke Paradigma Pendidikan Islam Multikultural:

Keberagamaan Indonesia dalam Keberagaman

Nilai-nilai yang tercakup dalam pendidikan multikultural dapat mengantarkan individu bersikap toleran, menghargai nilai-nilai kemanusiaan, dan suka pada perdamaian. Nilai-nilai itu sangat dibutuhkan untuk terciptanya masyarakat madani sebab masyarakat madani memiliki ciri antara lain; universalitas, supremasi hukum, menghargai perbedaan, kebaikan dari dan untuk semua, meraih kebajikan umum, dan menjunjung tinggi harkat dan martabat manusia. Jadi, orientasi dari pendidikan multikultural dalam Islam ialah tertanamnya sikap simpati, respek, apresiasi (menghargai), dan empati terhadap penganut agama dan budaya yang berbeda untuk meningkatkan kadar taqwa di sisi Allah swt. Karena Allah tidak melihat darimana ia berasal, seberapa tampan atau cantik, seberapa kaya, seberapa tinggi pangkat/jabatan, seberapa kuat badannya, tapi yang dilihat adalah seberapa besar tingkat ketaqwaannya.

Dengan demikian, pendidikan multikultural dalam Islam dijadikan sebagai usaha yang dilakukan secara sadar untuk mengembangkan kepribadian di dalam dan di luar sekolah yang mempelajari tentang berbagai macam status sosial, ras, suku, agama agar tercipta kepribadian yang cerdas dalam menghadapi masalah-masalah keberagaman budaya yang disesuaikan dengan nafas Islam sebagai sarana dalam mendekatkan diri pada Allah menuju makhluk yang mulia dengan taqwa. Oleh sebab itu, Rumusan tujuan akhir pendidikan Islam multikultural difahami sebagai jalan untuk membina peserta didik supaya tidak hanya mampu memahami dan menguasai materi pelajaran yang dipelajarinya akan tetapi diharapkan juga bahwa para peserta didik akan mempunyai karakter yang kuat untuk selalu bersikap demokratis, pluralis dan humanis. Karena tiga hal tersebut adalah ruh pendidikan multicultural (Qaimuddin, hal. 126).

Adapun Karakteristik pendidikan Islam multikultural antara lain: pertama, pendidikan yang berprinsip pada demokrasi, kesetaraan dan keadilan. Kedua, prinsip demokrasi, kesetaraan dan keadilan merupakan prinsip yang mendasari pendidikan multikultural, baik pada level ide, proses, maupun gerakan. Pendidikan yang berorientasi pada kemanusiaan, kebersamaan dan kedamaian untuk mengembangkan prinsip demokrasi, kesetaraan dan keadilan dalam kehidupan bermasyrakat, terutama di masyarakat yang heterogen, diperlukan orientasi hidup yang universal. Di antara orientasi hidup yang universal adalah kemanusiaan, kebersamaan, dan kedamaian.

Pendidikan yang mengembangkan sikap mengakui, menerima dan menghargai keragaman. Untuk mengembangkan orientasi hidup kepada kemanusiaan, kebersamaan dan kedamaiaan di tengah-tengah masyarakat yang 
majemuk diperlukan sikap sosial yang positif. Sikap sosial yang positif ini. Antara lain sebagai bentuk kesediaan untuk mengakui, menerima dan menghargai keragaman. Pendidikan multikultural memiliki perhatian kuat terhadap pengembangan sikap-sikap sosial yang positif tersebut. Dengan demikian, pendidikan multikultural menolak sikap-sikap sosial yang cenderung rasial, stereotip (mengejek objek tertentu) dan berprasangka buruk kepada orang atau kelompok lain yang berbeda suku, ras, bahasa, budaya dan agama.

Pengimplementasian pendidikan multikultural di sekolah mungkin saja akan mengalami hambatan atau kendala dalam pelaksanaannya. Ada beberapa hal yang harus mendapat perhatian dan sejak awal perlu diantisipasi antara lain sebagai berikut: (1) Perbedaan Pemaknaan terhadap Pendidikan Multikultural. (2) Munculnya Gejala Diskontinuitas. (3) Rendahnya Komitmen Berbagai Pihak. (4) Kebijakan-kebijakan yang Suka Akan Keseragaman (Arifudin, 2007, hal. 225-226).

Akhirnya, pendidikan multikultural bertujuan agar peserta didik dapat menghormati keanekaragaman budaya yang ada dan mendorong mereka secara nyata untuk dapat mengenali dan melenyapkan kecurigaan serta diskriminasi yangkerap kali terjadi di masyarakat. Jika kita melihat rumusan tujuan dari paradigma pendidikan berwawasan multikultural, maka menjadi sebuah keharusan paradigma ini diaplikasikan didalam proses pembelajaran disemua lembaga pendidikan Islam di Indonesia.

\section{Kesimpulan}

Pendidikan Islam Multikultural Sebagai proses pendidikan yang berprinsip pada demokrasi, kesetaraan dan keadilan; berorientasi kepada kemanusiaan, kebersamaan, dan kedamaian; serta mengembangkan sikap mengakui, menerima dan menghargai keragaman berdasarkan al-Qur'an dan hadis. Karena secara normatif, al-Qur'an sendiri sudah menegaskan bahwa manusia memang diciptakan dengan latar belakang yang beragam. Pendidikan Islam bukan hanya sekadar transfer of knowledge, tetapi lebih merupakan suatu sistem yang ditata di atas pondasi keimanan dan kesalehan, suatu sistem yang terkait langsung dengan Tuhan. Dengan demikian, pendidikan Islam adalah suatu kegiatan yang mengarahkan dengan sengaja perkembangan seseorang sesuai atau sejalan dengan nilai-nilai Islam. Sosok pendidikan Islam dapat digambarkan sebagai suatu sistem yang membawa manusia ke arah kebahagiaan dunia dan akhirat melalui ilmu dan ibadah.

Gagasan pendidikan multikultural di Indonesia adalah pendidikan untuk meningkatkan penghargaan terhadap keragaman etnik dan budaya masyarakat. 
Payiz Zawahir Muntaha dan Ismail Suardi Wekke Paradigma Pendidikan Islam Multikultural: Keberagamaan Indonesia dalam Keberagaman

Pendidikan multikultural dipersepsikannya sebagai jembatan untuk mencapai kehidupan bersama dari umat manusia dalam era globalisasi yang penuh dengan tantangan. Pembagunan pendidikan nasional haruslah menterjemahkan nilai-nilai yang terkandung pada budaya bangsanya. Budaya bangsa tersebut meniscayakan pemahaman terhadap tradisi-tradisi daerah yang tidak boleh diilangkan dalam proses pembelajaran. Proses pembelajaran haruslah melestarikan dan menghargai akar kebudayaan sebagai identitas nasional.

Tujuan utama pendidikan Islam multikultural untuk menegaskan seluruh lingkungan atau suasana pendidikan, sehingga dengan pendidikan Islam multikultural dapat meningkatkan respek atau perhatian terhadap kelompokkelompok budaya yang luas atau berbeda untuk mendapatkan pendidikan yang sama. Pendidikan Islam mulyikultural adalah paradigma pendidikan yang berorientasi pada kemanusiaan, kebersamaan dan kedamaian untuk mengembangkan prinsip demokrasi, kesetaraan dan keadilan dalam kehidupan bermasyrakat, terutama di masyarakat yang heterogen, diperlukan orientasi hidup yang universal. Di antara orientasi hidup yang universal adalah kemanusiaan, kebersamaan, dan kedamaian. Orientasi hidup yang universal ini merupakan titik orientasi bagi pendidikan multikultural. Dengan demikian, pendidikan multikultural menentang adanya praktik-praktik hidup yang menodai nilai-nilai kemanusiaan, kebersamaan, dan kedamaian seperti kekerasan, permusuhan, konflik dan individualistik. 


\section{Daftar Pustaka}

Akhiruddin, K. (2015). Lembaga Pendidikan Islam DI Nusantara. TARBIYA, 1(1).

Akhyar, Z. (2015). Implementasi Toleransi Antar Umat Beragama Di Desa Kolam

Kanan Kecamatan Barambai Kabupaten Barito Kuala. Jurnal Pendidikan Kewarganegaraan, 5(9).

Ali, N. (2010). Antologi Pendidikan Islam. Yogyakarta: Idea Press.

Ali, S. S., \& Arsyraf, A. (1986). Krisis Pendidikan Islam. Bandung: Risalah.

Aly, A. (2011). Pendidikan Islam Multikultural di Pesantren, Telaah terhadap

Kurikulum Pondok Pesantren Modern Islam Assalaam Surakarta.

Yogyakarta: Pustaka Pelajar.

An-nahlawi, A. (1992). Prinsip-Prinsip Dan Metode Pendidikan Islam Dalam Keluarga,Disekolah Dan Di Masyarakat. Bandung: Dipenogoro.

Arif, S. (2008). Orientalis dan Diabolisme Pemikiran. Jakarta : Gema Insani Press. Arifudin, I. (2007). Implementasi pendidikan Multikultural. Jurnal INSANIA, 12(2). Bagir, Z. A. (2010). Laporan Tahunan Kehidupan Beragama di Indonesia. Yogyakarta: CRCS.

Bagir, Z. A. (2011). Laporan Tahunan Kehidupan Beragama di Indonesia. CRCS: Yogyakarta.

Baidhawi, Z., \& Toyibi, M. (2005). Reinvensi Islam Multikultural. Surakarta: PSBPS UMS.

Bandel, K. (2011). Sastra Indonesia Mutkahir; Kritik Dan Keberagaman. Djournal Sastra Bumi Poetra.

Banks, \& Banks. (1997). Multicultural Education: Issues and Perspectives. New York: Allyn and Bacon.

Banks, J. A. (1987). Teaching Strategies for Ethnic Studies. USA: Allyn and Bacon. Byrne, P. (1995). Prolegomena to Religious Pluralism. London : Macmillan Press.

Drajat, Z., \& Muchtarom, Z. (n.d.). Islam Untuk Disiplin Ilmu Pendidikan. Jakarta: Bulan Bintang.

East, K. -F. (1999). A world of difference. Kuoni Travel \& JPM Publications.

Fay, B. (1998). Contemporary Philosophy of Social Science: A Multicultural Approach. Massachusetts: Blank Well Publishers.

Freire, P. (1986). Deschooling Society. New Jersey: Penguin Books.

Gunawan, K., \& Rante, Y. (2011). Manajemen Konflik Atasi Dampak Masyarakat Multikultural di Indonesia. Jurnal Mitra Ekonomi dan Manajemen Bisnis, 2(2). 
Payiz Zawahir Muntaha dan Ismail Suardi Wekke Paradigma Pendidikan Islam Multikultural:

Keberagamaan Indonesia dalam Keberagaman

Haningsih, S. (2008). Peran Strategis Pesantren, Madrasah dan Sekolah Islam di Indonesia. el-tarbawi, 1(1).

Harahap, A. R. (2006 ). Multikulturalisme Dalam Bidang Sosial. Jurnal Antropologi Sosial Budaya, II(1).

Haviland, W. A. (1988). Antropologi 2. Jakarta: Erlangga.

Ibrahim, H. (2008). Pendidikan Multikultural: Upaya Meminimalisir Konflik dalam Era Pluralitas Agama. 1(1).

Indonesia, K. A. (2010). Statistik Pendidikan Islam Tahun 2008/2009.

Indonesia, R. (2013). Undang-Undang SISDIKNAS (Sistem Pendidikan Nasional) (UU RI No. 20 Th. 2003). Jakarta: Sinar Grafika.

Madjid, N. (1994). Islamic Roots of Modern Pluralism: Indonesian Experience. Studia Islamika, 1(1).

Maksum, A. (2011). Pliuralisme dan multikuturalisme paradisma baru pendidikan Islam indonesia. Malang: Aditya Media Publishing.

Marimba, A. D. (1986). Pengantar Filsafat Pendidikan Islam. Bandung: AlMa'arif.

Muqoyyidin, A. W. (2012). Potret Konflik Bernuansa Agama Di Indonesia. Jurnal Analisis, 3(2).

Naim, N., \& Sauqi, A. (2008). Pendidikan Multikultural Konsep dan Aplikasi. Yogyakarta: Ar-Ruzz Media.

Pay, Y. (1990). Cultural Foundations of Education. USA: Merril Publishing Company.

Penyusun, T. (2010). Laporan Kebebasan Beragama/ Berkeyakinan dan Toleransi. Jakarta: the Wahid Institute.

Penyusun, T. (2011). Lampu Merah Kebebasan Beragama: Laporan Kebebasan Beragama dan Toleransi di Indonesia. Jakarta: the Wahid Institute.

Qaimuddin, S. (n.d.). Konsep Pendidikan Multikultural. Jurnal Al-Ta'dib, 7(2).

Steenbrink, K. A. (1986). Pesantren, madrasah, sekolah: pendidikan Islam dalam kurun moderen. Lembaga Penelitian, Pendidikan dan Penerangan Ekonomi dan Sosial.

Studies, C. f. (2010). Berdamai dengan Kekerasan: Fakta Tindakan Intoleransi dan Pelanggaran Hak Kebebasan Beragama/ Berkeyakinan di Jawa Timur.

Suardi, I. (2016). Harmoni Sosial Dalam Keberagaman Dan Keberagamaan Masyarakat Minoritas Muslim Papua Barat. KALAM, 10(2).

Susanto, E. (2006). Pendidikan Agama Berbasis Multikultural (Upaya Strategis Menghindari Radikalisme). KARSA, IX(1). 
p-ISSN: 1412-1697; e-ISSN: 2477-3816

http://jurnal.radenfatah.ac.id/index.php/intizar

Suyata. (2001). "Pendidikan Multikultural dan Reintegrasi Nasional: Implikasi Kebijakan" Pidato Pengukuhan Guru Besar. Yogyakarta: FIP-UNY.

Tilaar, H. A. (2004). Multikulturalisme, Tantangan-tantangan Global Masa Depan dalam Transformasi Pendidikan Nasional. Jakarta: Grasindo.

Wekke, I. S. (2015). Tradisi Pesantren dalam Konstruksi Kurikulum Bahasa Arab di Lembaga Pendidikan Minoritas Muslim Papua Barat. KARSA: Jurnal Sosial dan Budaya Keislaman, 22(1).

Wekke, I. S. (2016). CURRICULUM DEVELOPMENT IN MADRASA: EXPLORATION FROM MUSLIM MINORITY OF WEST PAPUA. Jurnal Pendidikan Islam, 3(1).

Wekke, I. S. (2016). Pengembangan Kurikulum Pendidikan Agama Islam Muslim Minoritas: Pesantren Nurul Yaqin Papua Barat. MADRASAH, 6(2).

Wekke, I. S., \& Lubis, M. A. (2016). A Multicultural approach in Arabic language teaching: creating equality at Indonesian pesantren classroom life. , 1(2). Sosiohumanika, 2(1). 
Payiz Zawahir Muntaha dan Ismail Suardi Wekke

Paradigma Pendidikan Islam Multikultural: Keberagamaan Indonesia dalam Keberagaman

Intizar, Volume 23, Nomor 1, 2017 